A N N A LES

UNIVERSITATIS MARIAE CURIE-SKŁODOWSKA LUBLIN - POLONIA

VOL. XXX, 2

SECTIO J

2017

Górnośląska Wyższa Szkoła Handlowa im. W. Korfantego w Katowicach.

Wydział Zarządzania

\title{
JANUSZ SZTUMSKI
}

janusz.sztumski@op.pl

\section{Praca ludzka jako wartość moralna}

Human Work as a Moral Value

\section{STRESZCZENIE}

Praca jest działalnością szczególnie doniosłą dla gatunku Homo sapiens, ponieważ dzięki niej zdołał się on wyodrębnić ze świata zwierzęcego oraz mógł tworzyć kolejne cywilizacje, które wskazują na jego psychofizyczny rozwój. Ale chociaż praca była decydującym czynnikiem stymulującym filogenetyczny rozwój ludzi i jest nim nadal, to jednak dostrzeżenie tego faktu stało się możliwe dopiero wówczas, gdy ludzie osiągnęli zdolność do naukowej refleksji nad pracą. Artykuł ten jest próbą skrótowego ukazania procesu kształtowania się poglądów na moralną wartość pracy ludzkiej oraz na uwarunkowania istniejących poglądów na ten temat.

Słowa kluczowe: praca ludzka; praca jako wartość; przegląd koncepcji; wartość moralna pracy

\section{OKREŚLENIE PRZEDMIOTU ROZWAŻAŃ}

Spośród różnorodnej działalności człowieka - postrzeganego gatunkowo - na szczególną uwagę zasługuje niewątpliwie praca, przez którą przetwarza on zasoby i siły przyrody zgodnie z rozmaitymi potrzebami. Dzięki pracy człowiek tworzy warunki zarówno swojej jednostkowej i społecznej egzystencji, jak i swojego rozwoju. Przez pracę ludzie osiągnęli także szczególną pozycję w świecie, wyrażającą się tym, że są jedynym gatunkiem, który jest w stanie poznawać i przeobrażać swoje naturalne środowisko zgodnie ze swoją wiedzą i pragnieniami, na miarę możliwości zmieniających się wraz z ich cywilizacyjnym rozwojem. 
Praca - jako celowa działalność ludzi, w trakcie której przekształcają przyrodę za pomocą narzędzi zgodnie ze swoimi pragnieniami i potrzebami - jest różnie ujmowana w takich naukach, jak filozofia, ekonomia, prakseologia, psychologia, socjologia i filozofia. Każda z nich wskazuje bowiem na te aspekty, które są szczególnie ważne z jej punktu widzenia. Na skutek tego spotykamy wiele definicji pracy ludzkiej, w których dochodzą do głosu różne spojrzenia na tę tak ważną działalność. Ale żadna $\mathrm{z}$ nich nie oddaje całego bogactwa zawartego w pojęciu pracy człowieka. Dlatego podanie definicji uwzględniającej wszystkie możliwe aspekty tego pojęcia jest trudne, jeśli w ogóle możliwe. Ponadto wspomniana trudność wzrasta na skutek tego, że w ciągu rozwoju społeczności ludzkich praca człowieka ulega przeobrażeniom w wyniku postępujących zmian techniki, technologii i organizacji pracy, zwiększania się jej zasięgu oraz bogacenia się jej form i treści. Przejawem tego są np. nowe dziedziny, w jakich człowiek może pracować oraz odkrywać nieznane dotąd możliwości skutecznego działania.

Zdolność do pracy wykonywanej za pomocą ciągle doskonalonych narzędzi, jaka cechuje istoty określane mianem Homo sapiens, przyczyniła się do wyodrębnienia się istot ludzkich ze świata zwierząt i do ich rozwoju gatunkowego. Przez pracę ludzie w ciągu wielu dziesiątków wieków doskonalili się zarówno pod względem fizycznym, jak i psychicznym, a rozwijając m.in. swoje ręce i mózg, osiągają coraz to większą sprawność manualną i intelektualną.

Zanim pojawiły się istoty ludzkie o delikatnych rękach pianisty lub chirurga i o odpowiednio rozwiniętym intelekcie nieodzownym dla wykonywania obu wspomnianych zawodów, upłynęło wiele czasu, przeminęło wiele pokoleń i cywilizacji, w których praca była powszechnym zjawiskiem decydującym o losach poszczególnych ludzi i całych społeczności lub społeczeństw.

W świetle nagromadzonych przez naukę danych można stwierdzić, że chociaż od bardzo dawna zdajemy sobie sprawę z doniosłości pracy dla zapewnienia człowiekowi warunków istnienia, to jednak znacznie wcześniej zastanawiano się nad moralną wartością pracy niż nad jej wartością ekonomiczną. Być może wynika to stąd, że w pierwotnych społecznościach oraz w społeczeństwach, które osiągnęły niski stopień cywilizacyjnego rozwoju, praca była świadczona przede wszystkim na zasadzie usług wzajemnych bądź przymusu stosowanego np. wobec jeńców lub niewolników (Thurnwald 1932, s. 166-169). To, że praca łączyła się z wdzięcznością i zobowiązaniem - w pierwszym przypadku, a z nakazem popartym siłą w drugim, spowodowało - jak sądzę - taką kolejność rozważań nad nią.

Wartościowanie pracy w kategoriach ekonomicznych w szerokim zakresie mogło wystąpić dopiero wówczas, gdy pojawiła się praca najemna. Wprawdzie z pracą najemną spotykamy się już od czasów formacji niewolniczej, jednak nie na tego rodzaju pracy przecież opierała się ówczesna gospodarka, lecz na pracy niewolniczej (por. Michałowski 1949, s. 15). Niewiele też zmienia się w tym 
względzie sytuacja $\mathrm{w}$ okresie feudalizmu, ponieważ podstawowa grupa producentów - pozostając w zależności poddańczej do swych panów - wykonywała również pracę za darmo. Dopiero w formacji kapitalistycznej, gdzie praca najemna, za którą płaci się robotnikowi, występuje w skali masowej, praca ludzka stała się także przedmiotem oceny ekonomicznej, nie przestając być nadal moralną wartością (por. Marks 1951, s. 188-211). I wówczas, zarówno w sferze teorii, jak i praktyki, pojawiło się zainteresowanie wydajnością pracy ludzkiej, a wraz z nim problem kształtowania ludzkich postaw wobec pracy, rzutujących na jej efektywność, m.in. przez odwoływanie się do moralnej wartości pracy.

Dokonujące się na przestrzeni wieków zasygnalizowane powyżej zmiany poglądów znajdują swoje odbicie w języku, którego analiza dostarcza wielu ciekawych danych dotyczących genezy słów, jakie występują w różnych nowożytnych językach i służą do określenia działalności człowieka zwanej pracą.

Otóż greckie słowo ergon, odpowiednik słowa „praca”, oznacza np. u Homera „ogromny ciężar”. Ale starożytni Grecy posługiwali się jeszcze innym terminem dla określenia tego pojęcia, mianowicie używali słowa ponos. Jak słusznie zauważa B. Biliński, „w pojęciu ponos zetknęły się dwa diametralnie różne aspekty szlacheckie i arystokratyczne: ponos jako pełna niebezpieczeństw droga do sławy i codzienny zwyczajny, ponos - jako trud małego człowieka" (Biliński 1948, s. 82).

Przypomnijmy tu wypowiedź Hezjoda, który twierdził, że „co tworzy ludzkie życie i zapewnia człowiekowi dostatek i radość życia, to praca, praca, praca”.

Łacińskie słowo labor, podobnie jak opus, oznacza pierwotnie 'mozół, trud, a nawet biedę'. Analogiczne znaczenia łączą się z niemieckim wyrazem Arbeit.

Dość interesująca jest geneza francuskiego słowa travail, które oznaczało pierwotnie narzędzie do ujarzmiania byków i narowistych koni przy podkuwaniu. Wywodzi się ono z łacińskiego słowa potocznego tripalium, używanego w VI w. w formie trepalium dla oznaczenia swoistego instrumentu tortury (por. Bloch, Wartburg 1950; Littre 1958). Stąd też travailler oznaczało z początku 'torturować, karać, cierpieć' i - co ciekawe - były to jego jedyne znaczenia w okresie od XIII do XVI w. Dopiero od XVII w. zaczęło być używane rzadziej w tym sensie i stopniowo łączono je ze słowem ouvrer, oznaczającym takie czynności, jak wyrabiać, wykonywać itp. Analogiczna jest geneza hiszpańskiego słowa trabajar.

Okazuje się, że analiza rozwoju znaczeń słów w języku, który jest odbiciem konkretnych warunków społeczno-ekonomicznych poszczególnych epok, może dostarczyć wielu godnych uwagi przyczynków do interesującego nas problemu dotyczącego rozwoju poglądów na temat oceny pracy ludzkiej. 
Chociaż praca ludzka - obiektywnie biorąc - jest warunkiem sine qua non istnienia i rozwoju człowieka, zarówno w jego filo-, jak i ontogenetycznym ujęciu, to jednak nie wszyscy ludzie przejawiają pozytywny stosunek do wartości, jaką stanowi praca. Okazuje się, że subiektywna ocena tej wartości jest często rozbieżna z jej obiektywnym znaczeniem. Można się o tym przekonać, analizując na przestrzeni wieków proces kształtowania się poglądów na wartość pracy w interesującym nas znaczeniu. O codziennych warunkach życia ludzi czasów pradawnych nie wiemy niestety zbyt wiele. Wiedza, jaką dysponuje historia starożytna, jest nader skromna, zwłaszcza jeżeli chodzi o wieki bardziej odległe od naszej ery. Jednak na podstawie zebranych przez uczonych faktów i ich analiz można wyrobić sobie w jakimś stopniu prawdopodobny pogląd na temat materialnych warunków życia i odpowiadających im stosunków społecznych ludzi żyjących w ustroju wspólnoty rodowej, czyli na niskim stopniu cywilizacyjnego rozwoju.

Otóż zdaniem wielu etnosocjologów, którzy zajmowali się m.in. gospodarczą problematyką społeczności żyjących na szczeblu rozwojowym odpowiadającym wspólnocie rodowej, praca była wysoko ceniona w tych społecznościach. Można z dużym stopniem prawdopodobieństwa przypuszczać, że była również ceniona w bardziej odległych czasach przez ludzi żyjących w analogicznym systemie społecznym. Dostrzeżono także to, że w tych społecznościach tolerowano ludzi leniwych, żyjących częściowo kosztem innych, jeśli tylko zachowywali się w granicach przyzwoitości, tzn. nie obnosili się ze swoim lenistwem.

Niemniej efekty osiągane przez działalność produkcyjną decydowały na ogół o godności i wartości osobistej poszczególnych ludzi. W wielu społecznościach rolniczych istniał np. zwyczaj wystawiania osiąganych plonów na widok publiczny. Popisywanie się rezultatami własnej pracy było niewątpliwie przejawem szlachetnego współzawodnictwa o tytuł najlepszego producenta, z którym łączył się swoisty autorytet i prestiż w danej społeczności. Znawcy problematyki spostrzegli jednak, że w niektórych społecznościach uważało się za niewłaściwe, by ktoś stojący niżej w hierarchii społecznej wystawiał bardziej okazałe plony niż człowiek zajmujący w niej wyższą pozycję (por. Thurnwald 1932, s. 11, 165). Na tej podstawie można sądzić, że o pozycji społecznej danego człowieka nie decydowały tylko osiągnięcia uzyskane przez pracę. Dostrzeżono ponadto fakt, że władza w tych społecznościach nie zawsze należała do ludzi, którzy byli najsprawniejsi w pracy produkcyjnej lub w walce, czego dowodem jest choćby występujące wówczas zjawisko gerontokracji.

Opierając się na zgromadzonych przez naukę materiałach, można wyrobić sobie pewien pogląd na ocenę pracy w ustroju wspólnoty rodowej. Otóż wydaje się, że w tej społecznej strukturze praca nie była wprawdzie wyłącznym źródłem wszelkich zaszczytów i godności, ale też nie była jeszcze utożsamiana z przekleń- 
stwem lub „dopustem bożym”, ponieważ odczuwano ją po prostu jako swoistą konieczność życiową, ciążącą w zasadzie w równym stopniu na wszystkich dorosłych i sprawnych ludziach. Dopiero w wyniku przeobrażeń społeczno-ekonomicznych, jakie nastąpiły w kolejnych wiekach na skutek przeobrażeń cywilizacyjnych, ten pozytywny stosunek do pracy zmienił się, a praca przestała być radością życia, stając się dla coraz to większej liczby ludzi przykrym obowiązkiem.

Niewątpliwie pierwsze jakościowo odmienne oceny interesującej nas działalności człowieka pojawiają się w okresie niewolnictwa, a więc w tej formacji społeczno-ekonomicznej, w której praca zostaje zepchnięta na barki niewolników. Odnosi się to do pracy ciężkiej, wykonywanej np. w kopalniach, większych wytwórniach, czyli w tzw. ergasteriach. Zdaniem K. Michałowskiego:

(...) praca górnika należała w Grecji do najcięższych, jakie znała starożytność. Panował tu najsurowszy reżim i dyscyplina, największy wyzysk sił i zdrowia człowieka. Jakkolwiek w Grecji los górników był względnie lżejszy od robotników pracujących w pustynnych kamieniołomach starożytnego Egiptu, to jednak na tle ogólnych warunków pracy na ziemiach greckich stanowili oni najbardziej upośledzoną klasę pracowników (Michałowski 1949, s. 22).

Jak wiadomo, formacja niewolnicza trwała stosunkowo długo i występowała w różnych społeczeństwach, nie tylko starożytnych. Z tego względu trzeba badać niewolnictwo w szerszych ramach czasowych i dostrzegać jego specyfikę w różnych okresach historycznych poszczególnych państw starożytnych. Stąd konieczne jest odniesienie badanego faktu nie tylko do danej formacji, ale i do konkretnych warunków i sytuacji historycznej danego społeczeństwa. Dlatego nie ma po temu podstaw, aby mówić o tym, że pogarda dla pracy ludzkiej była w starożytności powszechnym zjawiskiem, ponieważ jej ocena była zróżnicowana nie tylko w poszczególnych fazach rozwojowych niewolniczych państw, ale też różniła się w poszczególnych społeczeństwach, a nawet w środowiskach istniejących w ówczesnych państwach.

Zajmujący się tą problematyką - zwłaszcza w odniesieniu do Grecji - B. Biliński zauważa trafnie:

Jak nie możemy mówić o starożytnych Grekach jako jednolitym narodzie, lecz musimy wyróżnić poszczególne szczepy o odrębnych charakterach i poszczególne państwa o różnych aspektach ekonomicznych, socjalnych i politycznych, tak też przy analizie świadectw odnoszących się do pracy, mimo panującej niewolniczej formy produkcji, należy zwrócić uwagę na trzy główne zasadnicze ukierunkowane ekonomiczne kryteria, które sąd o pracy określają: $1^{0}$ inny jest stosunek do pracy w Koryncie i w miastach przemysłowo-handlowych, inny w Sparcie, inny znowu w Atenach, $2^{0}$ zmienia się on i ulega wahaniom w czasie, zależnie od rozwoju ekonomicznego i ustroju społeczno-politycznego poszczególnych państw: inny jest w epoce archaicznej, inny w klasycznej i znowu inny w epoce hellenistycznej, $3^{0}$ warstwy arystokratyczne i posiadające lekceważą pracę i ludzi pracy i pogardzają nimi, podczas gdy poszanowanie i powaga pracy wywodzi się od ludzi prostych i biednych, dla których praca była jedynym źródłem utrzymania (Biliński 1948, s. 101; van der Ven 1972, s. 21 i n.). 
Wspomina się o tym, że Periander - tyran Koryntu na przełomie VII i VI w. p.n.e. - wydał zakaz posługiwania się niewolnikami po to, aby zmusić w ten sposób wolnych obywateli do pracy. Podobnie Solon wprowadził w Atenach nakaz pracy i zalecał karać próżniaków, co nie było w tym mieście nowością, ponieważ prawo zakazujące próżnowania (czyli tzw. nomos argias) przypisywano już Drakonowi.

Trafne uwagi sformułowane przez B. Bilińskiego na temat oceny stosunku do pracy w starożytności odnoszą się nie tylko do Grecji. H. Sztajerman, opisując społeczeństwo zachodniorzymskie, zauważa, że „stosunek dla pracowitego ubóstwa był cechą charakterystyczną ideologii ludu, powstałej jako protest przeciw pogardzie dla pracy fizycznej, właściwej wyższym klasom inteligencji w społeczeństwie niewolniczym" (Sztajerman 1960, s. 124-125).

O tym, że pochwała pracy i ubóstwa była modna wśród plebsu, świadczą m.in. epitafia wykute na nagrobkach ludzi gminu, które „często upiększano także obrazami narzędzi pracy, które wskazywały na zawód wykonywany przez zmarłego" (Sztajerman 1960, s. 128).

Biorąc pod uwagę fakt, że w formacji niewolniczej występowały też pozytywne oceny pracy, wyrażane przynajmniej przez ludzi ubogich, którzy jako wolni żyli jednak z pracy najemnej, można wysnuć wniosek, iż dopiero wtedy pojawiały się opinie na ten temat zróżnicowane podziałem klasowym (por. Drumann 1860, s. 5; Rostovtzeff 1929, s. 42, 153-157). Na podstawie danych, jakimi dysponuje nauka o tej epoce, można ustalić pewne fakty, które rzucają światło na interesujący problem.

1. Otóż ludzi zawodowo pracujący fizycznie, których Grecy pogardliwie nazywali banansoi, tzn. rzemieślnikami, we wszystkich ówczesnych społeczeństwach zaliczano do najniższych warstw. Badania dotyczące struktury ówczesnych społeczeństw pozwalają stwierdzić istnienie takich oto zasadniczych warstw społecznych:

a) kapłani i władcy stanowiący szczyt hierarchii,

b) wojownicy tworzący warstwę średnią,

c) hodowcy lub rolnicy (w zależności od podstaw ekonomicznych danego społeczeństwa) składający się na najniższą warstwę, nie licząc oczywiście niewolników traktowanych przecież jako „narzędzia mówiące”.

Jak widać, status danej warstwy w hierarchii nie był wyznaczony ani przez jej aktywność w pracy produkcyjnej, ani przez jej użyteczność społeczną.

Za określoną dyskryminacją ludzi pracy przemawia niewątpliwie fakt, że kiedy na skutek postępu technicznego i podziału pracy pojawiła się nowa kategoria zawodowa, jaką stanowili rzemieślnicy, wtedy ich z kolei zaliczano do najniższej warstwy społecznej, i to nie tylko w starożytnej Grecji (por. Farrington 1954, s. 39). Ta niska ich ocena nie wynikała z małej wiedzy lub nikłych umiejętności 
ludzi zaliczanych do tej kategorii zawodowej, lecz opierała się ona na tym, że według mniemania starożytnych Greków, obecnego także w świadomości innych antycznych społeczeństw - praca wykonywana przez rzemieślników przytępiała zarówno cielesny, jak i duchowy rozwój człowieka (Drumann 1860, s. 60).

2. Godne uwagi jest również to, że w ówczesnych politeistycznych religiach bóstwa opiekujące się pracującymi ludźmi zajmowały z reguły niższe pozycje w panteonach, które były podobnie zróżnicowane, jak ówczesne społeczeństwa. Tacy bogowie wspierający pracujących, jak np. Hefajstos, Hermes i jego żona Atena-Ergane, występują w rzędzie bóstw pomniejszych, czyli stanowią dii minorum gentium (por. Poniatowski 1965, s. 134 i n.; Pszczołowski 1966, s. 66-68).

Ciekawym i kontrowersyjnym bóstwem jest Herkules, którego kultem otaczała początkowo tylko arystokracja. Stopniowo heros ten zaczął być czczony przez masy, stając się w ich mniemaniu ,pomocnikiem i obrońcą człowieka, bohaterem, który uzyskał cechy boskie za aktywną walkę ze złem i nieustanną pracę" (Sztajerman 1960, s. 139).

Zdaniem niektórych uczonych przedstawianie Hefajstosa jako kalekiego, bo przecież kulawego boga, było właśnie przejawem arystokratycznego stosunku do pracy. Ale nie jest wykluczone, że takie wyobrażanie sobie tego boga miało jeszcze inne podłoże. Jak wiadomo, tylko ułomni nie byli zdolni do brania udziału w wojnie i jedynie pracą swoich rąk musieli zdobywać środki niezbędne do życia, a co najwyżej przez wyrabianie broni mogli rywalizować z wojownikami. Bóstwo opiekujące się ludźmi skazanymi przez los na pracę było więc prawdopodobnie przedstawiane jako kalekie bóstwo (Biliński 1948, s. 53).

3. W kulturze antycznej pojawił się interesujący mit o tzw. wieku złotym czy raju, przedstawiający czasy, w których człowiek żył wolny od trudów pracy. Mit ten występuje w kilku wariantach: jest wspomniany przez Hezjoda w znanym poemacie dydaktycznym Prace $i$ dnie, przez Owidiusza w Metamorfozach oraz w Starym Testamencie. Spotykamy się także z dwojakim uzasadnieniem tezy głoszącej, że aurea prima sata est aetas:

a) w jednych ujęciach teza ta wynika ze skłonności do antropomorfizacji i personifikacji świata, czyli z wiary, że świat, podobnie jak człowiek, starzeje się, a w miarę tego procesu staje się coraz bardziej ograniczony w swoich możliwościach. Człowiek, który żył w okresie młodości świata, mógł więc bez trudu uzyskać od niego wszystko to, co było potrzebne do życia, natomiast człowiek żyjący w czasach, gdy świat się zestarzał, musi sam (i to usilnie) zdobywać środki niezbędne do egzystencji,

b) w bardziej zorientowanych religijnie koncepcjach mówi się o zbuntowaniu się świata przeciwko człowiekowi na skutek popełnienia przez człowieka „grzechu pierworodnego".

4. Negatywnie oceniali pracę produkcyjną starożytni filozofowie. Wprawdzie nie wszyscy, ale jednak wielu, i to znakomitych. Otóż Platon, Epikur czy Arysto- 
teles gardzili wręcz pracą, ponieważ była ona na współczesnym im etapie rozwoju środków produkcji przede wszystkim ciężkim mozołem, który uważali po prostu za działalność niegodną wolnego człowieka. Dostrzegali oni trafnie wiele negatywnych zjawisk z nią związanych, jak np. zmęczenie, które przytępia umysł i wyniszcza organizm. Dlatego zalecali raczej nieróbstwo i kontemplacje, a tym samym byli bardziej bliscy tradycji homeryckiej niż hezjodyjskiej. Ich arystokratyczny stosunek przejawiał się szczególnie w pogardzie dla pracy zarobkowej, czyli ergolabii.

Nisko cenił pracę wytwórczą Platon, jeżeli tych, którzy ją wykonywali, a więc rzemieślników i rolników, zaliczał do ostatniego stanu w ustalonej przez siebie hierarchii społecznej, a władzę był skłonny powierzyć filozofom-arystokratom, którzy oczywiście nie pracowali produkcyjnie (Platon 1958).

Stanowisko Platona jest o tyle dziwne, że już starszy od niego Hezjod głosił pogląd, że „hańbą jest nic nie robić”. Ale należy wspomnieć o tym, że i dla Hezjoda nie każda praca była godną człowieka wolnego. Uprzywilejowaną przez niego była praca rolnika. Szczególny szacunek dla niej był zresztą charakterystyczny nie tylko dla tego filozofa. Podobne stanowisko zajął później także Wergiliusz. W starożytności istniało bowiem szeroko rozpowszechnione mniemanie, że rolnik przez swoją działalność współuczestniczy poniekąd w dziele tworzenia będącego udziałem bóstw czy przyrody i z tego względu praca na roli nie poniża tak, jak praca rzemieślnika czy kupca.

Jednym z powodów, dla których Grecy i Rzymianie tak mało cenili ludzi pracujących fizycznie, było to, że praca fizyczna, nawet wykonywana w pozycji siedzącej przez niektórych rzemieślników, zniekształcała ludzkie ciało (Platon 1958; Arystoteles 1953).

Zwróćmy też uwagę na to, że pozytywna ocena działalności produkcyjnej rolnika uległa zmianie dopiero w średniowieczu, kiedy coraz bardziej tracił on posiadaną wcześniej niezależność społeczno-ekonomiczną i wreszcie został przypisany do ziemi. I wtedy wyższym poważaniem zaczęła cieszyć się praca rzemieślnika, który nie tylko miał większą niezależność, ale co więcej mógł się bogacić, korzystając z rozwoju ówczesnych miast, a tym samym mógł uzyskać pozycję patrycjusza i wynikające z tego tytułu przywileje.

Spośród filozofów greckich pozytywny stosunek do omawianego zagadnienia przejawiał niewątpliwie Demokryt, który właśnie w trudzie związanym z pracą widział istotny element wychowawczy. Podobną opinię wypowiadali również cynicy, których jedną z dewiz stała się teza „trud jest dobrem” (ponos agathon). Diogenes Laertios wspomina np. o szewcu-filozofie Symonie i, wyliczając wiele jego dialogów, po których pozostały niestety tylko tytuły, przytacza m.in. rozmowę zatytułowaną nader osobliwie, jak na dialogi filozoficzne owego czasu, mianowicie O pracy (Peri ton ergadzestai) (Biliński 1948, s. 42 i n.). 
Konieczność zapewnienia sobie środków utrzymania skłoniła do pracy Kleantesa z Assos, który był następcą Zenona, twórcy szkoły stoików, a także kolejnego przedstawiciela tej szkoły - Chryzypa (por. Diogenes Laertios 1969).

Z pewnymi przeobrażeniami poglądów filozofów na pracę spotykamy się następnie u schyłku starożytności, na gruncie filozofii rzymskiej. Co prawda, w tym okresie działa Cicero nawiązujący raczej do homeryckiej tradycji, twierdząc, że „zawody hańbiące uprawiają też rzemieślnicy, bo w rękodzielni nie może być nic szlachetnego" (Cicero 1960, s. 408).

W poglądach Cicerona, podobnie jak w prezentowanych wcześniej myślach Arystotelesa, zdaje się przejawiać prastary pogląd na pracę rzemieślnika - przekonanie, że polega ona na wyzwalaniu sił tkwiących w przedmiotach, które są poddawane obróbce. Stąd ludzi, którzy wykonywali skomplikowane wytwory rękodzielnicze, uważano za czarowników, a na skutek tego otaczano ich równocześnie podziwem i... pogardą. Dostrzegano sprawność ich rąk, ale oceniano ją specyficznie, jak zabiegi magiczne, co znajdowało swój wyraz w różnych formach dyskryminacji społecznej (Thurnwald 1932, s. 105-110).

Szczególnie widoczne zmiany w ocenie omawianego pojęcia zaznaczyły się przede wszystkim w poglądach stoików rzymskich, np. Seneka Mł. w swoich listach moralnych pisanych do Lucyliusza zalecał nie tylko dobre obchodzenie się z niewolnikami, którzy byli przecież ludźmi pracy, ale zachęcał również do szanowania samej pracy (Seneka 1961, s. 153-158, 170-172, 378).

Pomijając różne uprzedzenia, o których wspomnieliśmy wcześniej, niska ocena pracownika najemnego wynikała w starożytności zapewne także z jego sytuacji ekonomicznej. Jak wskazuje J. Day, nawet kwalifikowany pracownik w Grecji w III i II w. p.n.e. miał trudności z utrzymaniem swojej rodziny ze względu na niskie zarobki i wysokie ceny. Ponadto był stale zagrożony brakiem stałej pracy (Day 1942, s. 10). Nie lepsza była jego sytuacja ekonomiczna w późniejszych czasach w Imperium Rzymskim, jak to ukazują zebrane przez naukę informacje (por. Rostovtzeff 1929, s. 1-69; Gryglewicz 1957, s. 77).

Chrześcijaństwo w swojej doktrynie nawiązuje do mitu o „raju” i ,zbuntowaniu się świata” przeciwko człowiekowi, który popełnił "grzech pierworodny” (Wyszyński 1957, s. 94-99). Dlatego ideologowie chrześcijaństwa uważali pracę za konsekwencję tego grzechu, za efekt przekleństwa. Przypomnijmy wypowiedzi na ten temat zawarte w Starym Testamencie: „(...) przeklęta będzie ziemia w dziele twoim: w pracach jeść z niej będziesz po wszystkie dni żywota twego". Według tej koncepcji człowiek został po prostu skazany na pracę i przez nią musi przeciwstawiać się przyrodzie.

Byłoby błędem jednak sądzić, że stosunek chrześcijaństwa do pracy był jednolity $\mathrm{i}$ to nawet $\mathrm{w}$ pierwszej fazie rozwoju tej religii. Jest to rezultatem pomieszania różnych elementów, wśród których można w szczególności wyróżnić judajski bios praktikos i grecki bios teoretikos (por. Geoghegan 1945; Hauck 1921, 
s. 38-62). Ze względu na plebejski skład społeczny pierwotnych gmin chrześcijańskich poszczególni ideologowie tego kierunku odchodzili w pewnym stopniu od doktryny opartej na Starym Testamencie.

Otóż Paweł z Tarsu, który był wędrownym tkaczem zanim został apostołem, ostro potępiał lenistwo i jemu przypisuje się tezę, przypomnianą nam w XX w. W sposób niemniej kategoryczny, si quis non vult operari - non manducet. Potępienie próżniactwa występuje w słynnym drugim liście do Tesaloniczan. Wspomnijmy także opowieści o pracy rzemieślniczej św. Józefa oraz Jezusa Chrystusa.

W Nowym Testamencie pojawia się myśl, że praca jest kontynuacją przez ludzi stwórczego dzieła Boga, wyrażona właśnie przez Pawła z Tarsu (zob. 1 Kor 3,9). Myśl ta została następnie podjęta i rozwinięta przez św. Augustyna, który nauczał, że Bóg wiele rzeczy stworzył w formie zarodkowej, a człowieka wyposażył w zdolności i siły do kontynuacji aktu stwórczego i do aktywnego współdziałania z Bogiem (por. Kowalczyk 1986, s. 154-165).

Koncepcja Homo artifex, tzn. człowieka jako istoty uczestniczącej w doskonaleniu przyrody i siebie samego przez współpracę z Bogiem, znajduje swoje odbicie we współczesnej myśli teologicznej. Tytułem przykładu wspomnijmy takich jej przedstawicieli, jak J. Lacroix, P. Teilhard de Chardin, M.-D. Chenu. Znajduje ona też swoje odbicie w encyklice Gaudium et spes papieża Jana Pawła II.

Mimo niewątpliwych wpływów tradycji judejskiej ideologowie wczesnego chrześcijaństwa widzieli w pracy produkcyjnej nie tylko swoistą formę pokuty, ale także pewne wartości pozytywne. Upatrywano ich zarówno w fakcie, że przez pracę zdobywamy środki potrzebne do życia, jak i w tym, iż będąc źródłem wszelkiego dostatku, którym można się dzielić z innymi ludźmi (np. biednymi), stwarzała ona szansę realizowania nakazu miłości bliźniego.

Dalszą konsekwencją pozytywnej oceny było upatrywanie w pracy środka koniecznego dla utrzymania w zdrowiu ciała i duszy. Uważano, że człowiek, nic nie robiąc, gnuśnieje, a wówczas jego dusza staje się łatwiej łupem szatana na skutek grzesznych myśli i uczynków. Z tego właśnie faktu - jak zauważył nie bez racji A. Tilgher (1962, s. 13) - wynikał chrześcijański obowiązek dawania pracy ludziom niezatrudnionym, aby przez nią uchronić ich od niebezpieczeństw grożących ciału i duszy. Pomimo widocznej różnicy w ocenie ze strony ideologów wczesnego chrześcijaństwa i starożytnych myślicieli nadal nie dostrzegano jeszcze wszystkich wartości, jakie tkwią w pracy fizycznej, z którą łączyła się wówczas głównie działalność produkcyjna. Uważano ją więc ciągle jedynie za źródło pewnych cnót, ważnych ze względu na cel ostateczny.

$\mathrm{Z}$ bardziej pozytywną oceną spotykamy się dopiero u Augustyna Aureliusza, który w dziele De opere monachorum ostro potępiał nieróbstwo mnichów, traktujących pracę jako czynność niegodną ludzi przynależnych do stanu duchownego. Sądził ponadto, że praca nie tylko chroni przed upadkiem ciało i duszę, ale, co więcej, ożywia miłość braterską, która powinna przecież cechować zakonników. 
Do stanowiska Augustyna Aureliusza, który został podniesiony do godności świętego, nawiązywał żyjący około VI w. Benedykt z Nursji, założyciel znanego zakonu benedyktynów, który w działalności produkcyjnej widział nie tylko możliwość osiągania bogactw, ale także środek niweczący grzeszne pokusy i służący przede wszystkim zbawieniu człowieka. Podobne stanowisko reprezentował nieco wcześniej Pochomiusz, który w swoim klasztorze starał się łączyć ascezę z pracą (por. Ptaśnik 1959, s. 125-141).

Jeszcze bardziej radykalny w swoich poglądach na pracę i jej różnorodną wartość był Hugon ze św. Wiktora (1096-1141), a wskazuje na to jego dzieło pt. Eruditionis didascalicae libri VII, niezwykle poczytne w XII i XIII w., z którego korzystał m.in. Tomasz z Akwinu (por. Legowicz 1980, s. 199).

Pod wpływem Benedykta wiele innych zakonów zaczęło w pracy dostrzegać wartości moralne. Pomimo tej dość istotnej ewolucji, w jej ocenie nadal dominował pogląd, że praca nie ma żadnych wartości tkwiących w niej samej i stanowi jedynie swoistą technikę doskonalenia moralnego. $\mathrm{Z}$ tego punktu widzenia potępiano więc uczucia pojawiające się u ludzi dumnych ze swojego zawodu.

Od VIII w. zaczęła zarysowywać się pewna zmiana w dotychczasowych stanowiskach ideologów chrześcijaństwa, co przejawiało się m.in. w przeobrażeniach, jakim uległa reguła benedyktynów. Daje się zauważyć, że coraz większy nacisk kładziono na ascezę i liturgię (Kołaczkowski 1964, s. 119).

Godną odnotowania jest myśl Tomasza z Akwinu, który głosił, że obowiązek pracy cielesnej i duchowej jest prawem natury. Obowiązek ten był dla niego pierwotny w stosunku do religii i społeczeństwa, ponieważ wynikał z pierwszego nakazu pozytywnego, jaki otrzymywał człowiek od Boga po swym upadku. Wspomniany myśliciel uważał nawet, że człowiek, gdy żył jeszcze w raju, też musiał pracować, ale działalność ta była wówczas dla niego przyjemnością, a nie wysiłkiem (Haessle 1923, s. 29 i n.).

J. Le Goff na podstawie analiz podręczników pochodzących z różnych okresów, a przeznaczonych dla spowiedników, doszedł do wniosku, że można dostrzec istotne zmiany w poglądach Kościoła na wartość pracy ludzkiej. Wykazał on, że do XII w. dominowała tradycja starożytna, a praca była uważana raczej za „dopust boży”. Nic dziwnego, że była zalecana jako pokuta. Natomiast od XIII w. zaznaczyła się skłonność do brania pod uwagę w tej sytuacji przynależności stanowej spowiadanego. Wskazywano na przykład, że nakazywanie pracy jako pokuty ludziom gminu mija się z celem, ponieważ są oni raczej przyzwyczajeni nawet do ciężkiej pracy na co dzień (por. Lefrance 1959).

Spostrzeżenia Le Goffa są niewątpliwie interesujące, aczkolwiek - w świetle wcześniej przedstawionych danych na temat różnic $\mathrm{w}$ ocenie pracy występujących wśród reprezentantów wczesnego chrześcijaństwa - trudno się zgodzić z jego tezą, że do XII w. dominowała myśl, iż praca jest „dopustem bożym”. Było to po prostu jedno ze stanowisk, niekoniecznie dominujące. 
Warto wskazać, że przeciwko tendencji zmierzającej do uznania pracy za rodzaj pokuty występowały również powstałe wówczas sekty, nazywane przez Kościół heretyckimi. Tytułem przykładu wymieńmy Katarów, Waldensów, zwolenników Arnolda z Brescii, uczniów Franciszka z Asyżu czy wreszcie powstałą wśród franciszkanów w XIII w. sektę znaną pod nazwą Fraticelli. Członkowie wymienionych sekt wysoko cenili pracę rąk i potępiali próżniactwo ówczesnego kleru. Podobnie różne zakony żebrzące nauczały, że praca nie może być pokutą i zalecały inne środki umartwień. Stanowisko ich wydaje się tym bardziej uzasadnione, że zakony te działały wśród ludzi, dla których nawet ciężki trud był czymś powszechnym.

Z dalszym narastaniem skłonności do potępiania pracy fizycznej w wielu krajach europejskich możemy spotkać się znowu w XIV w., czyli w okresie zaostrzania się antagonizmów między patrycjatem a plebsem.

Zobaczmy, jakie były poglądy przedstawicieli Reformacji i Odrodzenia na pracę. Otóż stosunek wielkich reformatorów do pracy nie jest jednolity. Dla Lutra - podobnie jak i wielu średniowiecznych teologów - praca, spełniając równocześnie funkcję pokutną i wychowawczą, była przede wszystkim remedium peccati, czyli środkiem oczyszczającym z grzechów upadłego człowieka. Luter akcentował jednak o wiele mocniej, niż czyniono to dotąd, że każdy, kto jest zdolny do pracy, powinien ją wykonywać, a próżniactwo, podobnie jak lichwiarstwo, jest sprzeczne z naturą człowieka. W sporze na temat, co lepiej służy zbawieniu: praca czy życie w ascezie i kontemplacji - Luter opowiedział się za pracą. Upatrywał w niej podstaw życia społecznego, a w jej rozwoju doszukiwał się przyczyn zróżnicowania społeczeństwa. Oryginalna jest jego teza, że praca stanowi formę służby Bogu. Ponadto nauczał, że najlepszym pełnieniem tej służby jest doskonałe wykonywanie swego zawodu. Z tezy tej wynikał wniosek, że każda praca jest Bogu równie miła, jeżeli jest dobrze wykonywana. Toteż od czasów Lutra niemiecki wyraz Beruf nabrał religijnego zabarwienia, stając się synonimem ,powołania” i ,zawodu”. Dodajmy, że z analogicznym rozumieniem słów oznaczających zawód możemy spotkać się w innych krajach protestanckich. Stanowisko Lutra przyczyniło się więc niewątpliwie do podniesienia społecznej rangi pracy, a w dalszej konsekwencji wywarło wpływ na wzrost szacunku dla niej.

Poglądy Kalwina były jeszcze bardziej skrajne niż myśli Lutra i wynikały z jego osobliwej filozofii życia, opartej na wierze w przeznaczenia. Głosił na przykład, że wszyscy muszą pracować, ponieważ po prostu taka jest wola boża, a równocześnie nie pozwalał człowiekowi pożądać owoców swojej pracy. Z tego paradoksalnego nakazu podejmowania nieustannego wysiłku związanego z pracą w celu równie nieustannego wyrzekania się korzyści jego rezultatów wynika swoista dyrektywa ekonomiczna, tak bardzo - jak to się okazało później - przydatna dla rodzącego się kapitalizmu. Zdaniem Kalwina praca chaotyczna jest Bogu niemiła; wysoko cenił natomiast pracę wykonywaną metodycznie, w sposób zdy- 
scyplinowany, racjonalny i jednolity. Potępiał kontemplację, ponieważ uważał, że przez rozmyślania nie można ani przeniknąć tajemnic bożych, ani wpłynąć na swoje zbawienie. Jego koncepcje wychodzily zatem naprzeciw potrzebom powstającego kapitalizmu, przyczyniając się do ukształtowania człowieka nowego typu: o silnej woli, aktywnego, surowych obyczajów, gotowego do podejmowania nawet ciężkiej pracy z głębokich pobudek religijnych (por. Weber 1905; Troeltsch 1906). Trafnie więc zauważył cytowany wcześniej Tilgher, że kalwinizm dostarczył ideologicznych podstaw przerażającej dyscyplinie współczesnej fabryki i panującemu w niej reżimowi.

Jeszcze bardziej radykalny w swych poglądach był wywodzący się z kalwinizmu purytanizm, którego reprezentanci głosili, że jedną z istotnych powinności człowieka jest osiąganie przez pracę możliwie maksymalnego zysku, ale nie dla pieniędzy ani osobistego zadowolenia, lecz w celu uzyskania większego błogosławieństwa. Im większy zysk z pracy, tym większa pewność - ich zdaniem - że się dobrze służy Bogu. Z zaleceń tych wynikał osobliwy wniosek: chęć życia w ubóstwie jest najwyższą formą oddawania złej przysługi chwale bożej. W ten sposób dążenie do maksymalnego zysku przez pracę doczekało się po raz pierwszy w historii nie tylko poparcia religijnego, ale nawet uświęcenia-laborare est orare. Moralista purytański powtarza tę dawną maksymę, nadając jej nowe doniosłe znaczenie w nowych czasach. Idealizowana przezeń praca nie jest jedynie koniecznością naturalną lub karą za grzech Adama - jest sama w sobie rodzajem ascetycznej dyscypliny, surowszej od dyscypliny jakiegokolwiek zakonu żebrzącego, dyscypliny z woli Boga, polegającej nie na umartwianiu się w samotności, lecz na sumiennym i dokładnym wypełnianiu świeckich obowiązków na stanowisku pracy (Tawney 1963, s. 228).

Stosunek myślicieli Odrodzenia do pracy był zróżnicowany. Twórcy znanych utopii, jak np. T. More (1954) i J. Campanella (1955), wysoko cenili jej moralne walory. Z kolei F. Bacon (1954) i F. Rabelais (1949), chociaż nie byli entuzjastami pracy, doceniali jej znaczenie i ganili życie próżniacze. Natomiast F. Montaigne zalecał pracę ze względów wychowawczych i wskazywał na jej ważną rolę w kształtowaniu człowieka. Tak wybitny przedstawiciel omawianego okresu, jakim był Erazm z Rotterdamu, przejawiał raczej stosunek arystokratyczny do pracy i głosił tezy przypominające poglądy tych myślicieli starożytnych, którzy nawiązywali do tradycji homeryckiej.

Myśliciele XVII i następnych wieków prezentowali na ogół pozytywne oceny pracy. Na poważne znaczenie wychowawcze pracy oraz na jej funkcje poznawcze wskazywał J. Locke. Dla racjonalistycznie i materialistycznie zorientowanych myślicieli Oświecenia praca była cnotą. Voltaire w swym pamflecie pt. Kanddyd pisał, że „praca oddala od nas trzy wielkie niedole: nudę, występek i ubóstwo" (Voltaire 1951). 
Na potrzebę darzenia szacunkiem zawodu rzemieślników wskazywali J. le Rond d'Alembert, C.A. Helvetius, D. Diderot, a J.J. Rousseau mówił nawet o obligatoryjnym charakterze ich działalności. Podobne stanowisko zajmowali przedstawiciele naszego Oświecenia, jak np. H. Kołłątaj (1955) i S. Staszic (1954, 1959), głoszący, że praca jest koniecznością, i to nawet biologiczną.

Na kształtującą dzieje ludzkości rolę pracy wskazywał J.G. Herder. Natomiast J.G. Fichte był zdania, że obowiązek pracy warunkuje zarówno fizyczny, jak i moralny rozwój jednostki ludzkiej i dlatego domagał się, aby państwo gwarantowało obywatelowi możliwość uzyskania zatrudnienia.

Inny wielki filozof niemiecki - G.W.F. Hegel - wskazywał, że ludzkość dzięki swojej pracy tworzy własną historię. Jednak teza ta nie była wówczas nowością, ponieważ podobne poglądy nieco wcześniej głosił B. Franklin (1827).

Jednakże, pomimo wysokiego uznania wyrażanego powszechnie przez ówczesnych intelektualistów, utrzymywał się na ogół pogląd (zwłaszcza wśród wyższych warstw społeczeństw zachodnioeuropejskich), że działalność zarobkowa, w szczególności zaś praca fizyczna, która niszczy ręce, to czynność niegodna człowieka przynależnego do tych warstw. Uważano więc, że człowiek z wyższych warstw społecznych powinien raczej unikać jej jako zajęcia poniżającego i żyć kosztem innych (Chałasiński 1949; Ossowska 1963, s. 200-219). Człowiek utrzymujący się z dziedzicznego majątku i pracy innych (tzw. niebieski ptak) czy nawet przysłowiowy „pieczeniarz” był w tych warstwach wyżej ceniony niż ten, kto sam zarabiał na swoje utrzymanie, zwłaszcza ciężką pracą.

W XIX w. pod wpływem procesów społeczno-ekonomicznych spowodowanych rozwojem industrializacji oraz ruchów społeczno-politycznych związanych z pojawieniem się coraz liczniejszej klasy pracowników najemnych i tzw. socjalizmu utopijnego, a następnie marksowskiego, dokonały się istotne przeobrażenia w ocenie pracy.

Udział socjalistów utopijnych w procesie emancypacji działalności produkcyjnej jest niewątpliwie godny odnotowania. Już około $1840 \mathrm{r}$. tezy ich programu obejmowały: obowiązek i prawo do pracy, prawa do wytworzonego integralnego produktu, prawa do pracy radosnej (J. Fourier) oraz prawo do organizowania się ludzi pracujących (H. de Saint-Simon) (Lefrance 1959).

Socjaliści utopijni pierwsi wysunęli tezę, że przekleństwo upatrywane w pracy nie ma wcale boskiej genezy, ponieważ negatywne jej skutki są następstwem rozwoju społeczno-ekonomicznego, który doprowadził do zróżnicowania ludzi i wyzysku, zwłaszcza najbiedniejszych.

Na szczególną uwagę zasługują również ukazane przez P.J. Proudhona tak istotne właściwości pracy, jak np.:

a) jedność, przejawiająca się w tym, że praca jest jedna i identyczna w swoim planie oraz nieokreślona $\mathrm{w}$ swoich zastosowaniach jako twórczość 
sama w sobie, a także jej przedmiot jest jeden - mianowicie świat materialny jest przekształcony i opanowany przez człowieka,

b) pierwotność moralna, wyrażająca się w tym, że przez pracę bardziej niż przez walkę zbrojną ukazuje się męstwo i w większym stopniu niż przez pobożność osiąga się sprawiedliwość, toteż jeśli kiedykolwiek ludzkość stanie się szczęśliwa, to szczęśliwość ta zostanie osiągnięta właśnie dzięki niej,

c) intelektualna wyższość, która tkwi w tym, że kto posiada swoją myśl we „wgłębieniu swojej ręki” - jak mówił, tzn. potrafi ucieleśnić ją przez pracę, jest zawsze człowiekiem o większej inteligencji niż ten, kto daną myśl nosi w głowie i nie jest w stanie inaczej jej wyrazić, jak tylko przez formułkę (Lefrance 1959, s. 22).

Zdaniem K. Marksa i F. Engelsa praca doprowadziła człowieka do wyodrębnienia się ze świata zwierzęcego i zadecydowała o jego aktualnych właściwościach psychofizycznych oraz o ich rozwoju. Myśliciele ci zwrócili także uwagę na nieznane dotąd zjawisko powstałe $\mathrm{w}$ związku z działalnością produkcyjną, mianowicie na alienację człowieka w stosunku do przyrody, własnego gatunku, pracy $\mathrm{i}$ jej produktu.

Na czym polegają wspomniane alienacje? Otóż człowiek - jako jedyna istota spośród żyjących istot - przeobraża przyrodę według swoich pragnień i upodobań oraz podporządkowuje ją sobie w miarę posiadanych możliwości, które wzrastają wraz cywilizacyjnym rozwojem człowieka. Przeobrażając i przetwarzając przyrodę, tworzy świat własnych wytworów oddzielających go od przyrody. Im bogatszy staje się wspomniany świat, tzn. im wyższą ludzie osiągają cywilizację, tym bardziej oddalają się od przyrody. Na skutek tego ludzie zapominają o swoim związku z przyrodą, chociaż stanowią jej element i są skłonni uwierzyć w to, iż człowiek pojawił się na zasadzie deus ex machina, a nie w to, że wyłonił się z przyrody. I w tym osobliwym postrzeganiu przez człowieka swoich związków ze środowiskiem naturalnym przejawia się jego alienacja z przyrody.

Jednym z następstw rozwoju działalności produkcyjnej człowieka i podziałów pracy jest proces rozwarstwienia społeczności ludzkich oraz ukształtowanie się tak dalece zróżnicowanych ze względu na swoją sytuację społeczną antagonistycznych klas i warstw społecznych, że mogło się wydawać, iż przynależne do nich istoty są przedstawicielami rożnych gatunków. Niewolnik np. był dla swego pana na ogół tylko narzędziem mówiącym, a nie istotą tego samego gatunku. W wyniku omawianej alienacji człowiek człowiekowi stał się istotą obcą, czemu dawało wyraz porzekadło znane w starożytności, iż homo homini lupus est, tzn. człowiek człowiekowi jest wilkiem.

Odkąd praca produkcyjna stała się dla znacznej części ludzi narzuconym im obowiązkiem, egzekwowanym niekiedy w okrutny sposób przez tych, którzy żyli właśnie z ich pracy, przestała być ona dla nich źródłem satysfakcji z uczestnictwa 
w społecznym procesie przeobrażania świata i stała się przekleństwem dla istot zmuszonych do wyniszczającej ich pracy ponad siły.

Alienację człowieka w stosunku do pracy Marks przedstawiał w następujących słowach:

(...) praca jest dla człowieka czymś zewnętrznym, tzn. nie należy do jego istoty (...) robotnik nie potwierdza się w swojej pracy, lecz zaprzecza, nie czuje się zadowolony, lecz nieszczęśliwy, nie rozwija swobodnie energii fizycznej i duchowej, lecz umartwia swoje ciało i rujnuje się duchowo (...) czuje się zatem sobą dopiero poza pracą (...) praca jego nie jest dobrowolna, lecz narzucona (...). Nie jest ona zaspokojeniem potrzeby pracy, lecz tylko środkiem do zaspokojenia potrzeb poza nią. Jej obcość uwidacznia się wyraźnie w tym, że gdy tylko nie ma przymusu fizycznego czy jakiegoś innego, człowiek ucieka od niej jak od zarazy.

Wreszcie alienację człowieka w stosunku do produktu swej pracy Marks upatrywał w tym, że:

(...) robotnik ubożeje tym bardziej, im więcej produkuje bogactwa (...) staje się towarem tańszym, im więcej towarów wytwarza. Praca wytwarza nie tylko towary, wytwarza samą siebie i robotnika jako towar (...) przedmiot, który praca wytwarza, jej produkt, przeciwstawia się jej, jako jakaś obca istota, jako siła niezależna od wytwórcy (por. Marks, Engels, 1960, s. 550-551, 547-548).

Marksowska ocena skutków alienacji pracy stała się jednym z elementów podstawy ideologii proletariatu, która odegrała istotną rolę w kształtowaniu się współczesnego ruchu robotniczego i jego partii oraz organizacji zawodowych.

Do poglądów tych nawiązywało wielu myślicieli, którzy właśnie w pracy upatrywali podstawy nowej moralności i widzieli w niej czynnik integrujący skłócone społeczności ludzkie. Rezultatem rozwoju marksistowskiej idei pracy jest powstanie nowego humanizmu, który przejawia się we współczesnych koncepcjach etycznych, eudajmonistycznych czy estetycznych, oraz pojawienie się swoistego heroizmu pracy i związanego z nim kultu pracy.

Jak wspomniano wcześniej, wielu ideologów chrześcijaństwa wypowiadało się pozytywnie o pracy, ale - jak twierdzi o. M.-D. Chenu (1963) - tzw. teologia pracy pojawiła się dopiero w naszych czasach, podczas gdy „teologia wojny” istniała już w XIV w. Widać więc, że dopiero rewolucja przemysłowa i pojawienie się na widowni dziejów proletariatu jako nowej siły społeczno-politycznej skłoniły Kościół do poważniejszego zainteresowania się tym zagadnieniem (Thils i in. 1962). Można by tu wspomnieć także o ruchu na rzecz świata pracy realizowanym przez Kościół poprzez tzw. księży-robotników.

Warto przy tym wskazać, że niektórzy teologowie nawiązujący do marksistowskiej teorii pracy i akceptujący mniej czy bardziej jawnie teorię alienacji nie dostrzegają jednak ambiwalentnej roli pracy w rozwoju człowieka. Twierdzą na przykład, że w uprzemysłowionych społeczeństwach stał się on w pewnym sensie 
animal laborans i nie dostrzegają równocześnie tego, że dzięki pracy jest przecież także Homo sapiens (Scheler 1960, s. 193 i n.).

Poglądy przedstawicieli myśli katolickiej na pracę ulegały ewolucji w miarę rozwoju przeobrażeń zachodzących we współczesnym świecie. Widać to wyraźnie na przykładzie studium ks. C. Bartnika pt. Teologia pracy ludzkiej. Wspomniany autor przyznaje, że w przeszłości katolicka interpretacja pracy była, obiektywnie biorąc, zgodna $\mathrm{z}$ interesami klas posiadających, zmierzając do wsparcia ustroju feudalnego. Ponadto dostrzega ten fakt, iż na przemiany współczesnej, postępowej, katolickiej koncepcji pracy wywarł istotny wpływ również marksizm (Bartnik 1977, s. 48-51).

Dotychczasowe refleksje prowokują pytanie: czy z uwagi na to, że doniosła rola pracy i jej wartość moralna zostały potwierdzone przez teorię i praktykę, a także uznane przez kapitalizm i socjalizm oraz przez wielu współczesnych teologów, można powiedzieć, że praca stała się, np. u nas obecnie, rzeczywiście najwyższą wartością cieszącą się powszechnym uznaniem? Jeśli weźmiemy pod uwagę rozmaite uroczyste deklaracje oficjalne lub prywatne, to na ich podstawie można oczywiście sformułować odpowiedź pozytywną. Kiedy jednak przyjrzymy się opiniom i postawom ludzi z różnych warstw społecznych, wówczas można stwierdzić, że w powszechnym odczuciu praca nie jest wcale wysoko ceniona.

Znakomita większość pracujących czuje się ludźmi dopiero po pracy, a nie w czasie jej trwania. To poza nią realizują swoje głębsze zainteresowania. Nie brak też takich, którzy pracę swoją traktują po prostu jako przykrą konieczność, związaną z potrzebą zdobywania środków niezbędnych do życia, chociaż równocześnie uświadamiają sobie, że właśnie ta działalność umożliwia im realizację różnych osobistych pragnień i stwarza warunki osiągania przyjemności z tytułu współtworzenia różnych dzieł, kierowania innymi, podejmowania ryzyka, wyróżniania się osiągnięciami produkcyjnymi, naukowymi i artystycznymi itp.

Przyczyny tego zjawiska są nader złożone i wynikają zarówno z obiektywnych, jak i subiektywnych uwarunkowań. Do obiektywnych zaliczamy przede wszystkim splot warunków społeczno-ekonomicznych, które powodują, że o pozycji danego człowieka nie decyduje tylko i wyłącznie jego aktywność w działalności produkcyjnej lub innej, w tym społecznie użytecznej, a także wynikającą z tego tytułu przydatność społeczną. Wiadomo ponadto, że wciąż jeszcze znacznie lepiej powodzi się wielu niepracującym, czyli tzw. niebieskim ptakom. Cieszą się oni, niestety, większym powodzeniem w licznych środowiskach społecznych niż ludzie uczciwie i ciężko pracujący fizycznie czy umysłowo, zdobywający w trudzie i znoju środki do życia i swoją pozycję społeczną. Można także ubolewać nad tym, że nadal często ludzie umiejący się dobrze urządzić kosztem innych i przy minimalnym wysiłku własnym mają większy prestiż niż ci, którzy swoją karierę zawdzięczają ciężkiej i wytrwałej pracy. W przeciwieństwie np. do USA 
brak u nas ideologii wskazującej na możliwość zrobienia kariery przez ciężką pracę, choćby pucybuta.

Na kształtowanie się wspomnianych postaw niemały wpływ wywierają - jak się zdaje - stosowane zasady wynagradzania, które nie uwzględniają w dostatecznym stopniu rozmiaru wysiłku lub zakresu odpowiedzialności. Trudno nie dostrzec też złych wpływów rozmaitych łatwych sposobów dorabiania się nawet dużych pieniędzy, które tworzą mity i złudzenia w skali masowej o możliwościach łatwego zdobycia wielkich fortun, nie tylko niezależnie od pracy, ale nawet po to, aby się od niej wyzwolić.

Z warunków subiektywnych trzeba - jak sądzę - wymienić tkwiącą w świadomości wielu ludzi wiarę, że praca jest po prostu „dopustem bożym”. Otóż wiara ta, w przypadku ludzi głęboko wierzących, jakich w naszym społeczeństwie jest przecież niemało, nie powinna działać demobilizująco. Ludzie ci bowiem powinni zdawać sobie z tego sprawę, że grzechem byłoby przeciwstawianie się wspomnianemu dopustowi. Natomiast ludzie bardziej obojętni w stosunku do religii będą skłonni raczej uważać, że od owego „dopustu” godzi się uwolnić, a w najgorszym razie pomniejszyć jego rozmiar, co m.in. znajdzie swoje odbicie w lekceważącym stosunku do pracy. Być może ze względu na istniejący wzrost bezrobocia w skali globalnej postawa ta będzie ulegać zmianie.

\section{ZAKOŃCZENIE}

Z uwagi na postępujące zmniejszanie się zapotrzebowania na pracę żywą nasuwa się myśl, że o ile wcześniejsze cywilizacje były oparte na pracy ludzkiej, o tyle cywilizacja XXI w. staje się cywilizacją bezrobocia, czyli cywilizacją, w której praca ludzka przestaje mieć nie tylko masowy charakter, jak to miało miejsce wcześniej, ale też traci swoje pierwotne znaczenie. I tego rodzaju zmiana może spowodować różnorodne i nieznane dotąd konsekwencje w życiu społeczno-gospodarczym poszczególnych społeczeństw, w których będą one miały miejsce.

Uważam, że warto wskazać przynajmniej na takie dwa następstwa:

1. Dla ludzi pozbawionych zatrudnienia, a zwłaszcza doświadczonych trwałym bezrobociem, zabraknie tak istotnego czynnika stymulującego psychofizyczny i społeczny rozwój człowieka, jakim jest praca.

2. Co będzie mogło w przyszłości oddalić od coraz liczniejszych zbiorowości ludzi owe trzy niedole, na które wskazywał Voltaire, tzn. nudę, występek i ubóstwo? Czy na podstawie dotychczasowych doświadczeń związanych z zagospodarowaniem czasu wolnego możemy pocieszać się, że oglądanie telewizji i gry komputerowe spowodują zanik nudy i skłonią ludzi do cnotliwego życia?

Odrębnym problemem jest niewątpliwie sprawa ubóstwa, które niestety wykazuje tendencje wzrostowe $\mathrm{z}$ uwagi i na wzrost bezrobocia, i na postępujące 
rozwarstwienie poszczególnych społeczeństw ze względu na stopień zamożności, spowodowane przez obowiązujące zasady podziału dochodu narodowego, mniej lub bardziej dalekie od zasad sprawiedliwości społecznej.

Jeżeli rozszerzać się będzie zjawisko bezrobocia, a dalszy rozwój cywilizacyjny będzie wynikiem pracy coraz mniejszej liczby wysokokwalifikowanych pracowników uczestniczących w kontynuacji kolejnych rewolucji naukowo-technicznych, to przyszła cywilizacja będzie dziełem elit kompetencji, złożonych z wysokiej klasy specjalistów z różnych dziedzin, a więc z ludzi o dużej wiedzy i dużych umiejętnościach, a nie dziełem pracujących mas, tworzących dotąd ekonomiczne podstawy cywilizacji (por. Sztumski 1977, s. 22 i n.).

Nie można jednak zapominać o tym, że współczesne społeczeństwa wysoko rozwinięte to właśnie społeczeństwa masowe - jak to zauważył nie bez racji J. Ortega y Gasset - czyli takie, które w swojej istocie są określone przez masy. Są to zatem społeczeństwa, na których istnieniu i rozwoju wywiera piętno masowa produkcja i konsumpcja oraz kultura masowa. Zauważmy przy tym, że istniejące w nich masy są świadome siły i ta świadomość utrwaliła się wśród nich przynajmniej od 200 lat, tzn. od czasów Wielkiej Rewolucji Francuskiej (por. Ortega y Gasset, 1982, s. 7-8).

Być może pozbawione pracy masy społeczeństwa tej przyszłej cywilizacji elit kompetencji będą stawały się coraz bardziej biernym elementem wspomnianej cywilizacji. Tego rodzaju masy mogą ulegać postępującej degeneracji psychofizycznej i społecznej ze względu na brak tak istotnego bodźca rozwoju osobniczego człowieka, jakim jest praca. A wówczas mogą stać się masą ludzi podatnych na manipulacje dokonywane przez ambitnych, ale nie zawsze zrównoważonych psychicznie osobników żonglujących populistycznymi hasłami. Istnieje zatem niebezpieczeństwo, że owe masy będą decydowały o warunkach życia i rozwoju społeczeństw wspomnianej osobliwej cywilizacji przyszłości. Stanie się to także poważnym wyzwaniem dla przedstawicieli nauki, zwłaszcza socjologów, pedagogów i polityków społecznych.

\section{BIBLIOGRAFIA}

Arystoteles (1953), Polityka, Wrocław: Zakład im. Ossolińskich.

Bacon F. (1954), Nowa Atlantyda, Warszawa: IW PAX.

Bartnik C. (1977), Teologia pracy ludzkiej, Warszawa: IW PAX.

Biliński B. (1948), O Hezjodejski aspekt starożytności. Praca w starożytnej Grecji, „Archeologia. Rocznik Polskiego Towarzystwa Archeologicznego", t. 2.

Bloch O., Wartburg W. von (1950), Dictionnaire etymologique de la langue française, Paris: Presses Universitaires de France.

Campanella J. (1955), Miasto słońca, Wrocław: Zakład im. Ossolińskich.

Chałasiński J. (1949), Społeczna genealogia inteligencji polskiej, Warszawa: Czytelnik. 
Chenu M.-D. (1963), Ku powszechnej cywilizacji pracy, Warszawa: PWN.

Cicero (1960), Pisma filozoficzne, t. 2, Warszawa: PWN.

Day J. (1942), An Economic History of Athens under Roman Domination, New York: Columbia University Press.

Diogenes Laertios (1969), Żywoty i poglądy sławnych filozofów, Warszawa: PWN.

Drumann W. (1860), Die Arbeiter und Communisten in Griechenland und Rom, Königsberg.

Farrington B. (1954), Nauka grecka, Warszawa: PWN.

Geoghegan A.T. (1945), The Attitude Towards Labor in Early Christianity and Ancient Culture, Washington: The Catholic University of America.

Gryglewicz F. (1957), Najemny robotnik w Palestynie za czasów Chrystusa Pana, „Roczniki Teologiczno-Kanoniczne", t. 5, z. 1.

Haessle J. (1923), Das Arbeitsethos der Kirche. Nach Thomas von Aquin und Leo XIII, Freiburg.

Hauck F. (1921), Die Stellung der Urchristentums zu Arbeit und Geld, Gütersloh.

Kołaczkowski J. (1964), Wspólnoty chrześcijańskie, Kraków: Znak.

Kołłątaj H. (1955), Porządek fizyczno-moralny, Warszawa: PWN.

Kowalczyk S. (1986), Podstawy światopoglądu chrześcijańskiego, Wrocław: Tum.

Lefrance G. (1959), Le travail et l'homme, Textes des conferences et des entretiens organises par les Recontres Internationals de Geneve.

Legowicz J. (1980), Zarys historii filozofii. Elementy doksografii, Warszawa: Wiedza Powszechna.

Littre E. (1958), Dictionnaire de la langue francaise, Paris: Presses Universitaires de France.

Marks K. (1951), Kapitał, t. 1, wyd. 3, Warszawa: PWN.

Marks K., Engels F. (1960), Dzieła, t. 1, Warszawa: PWN.

Michałowski K. (1949), Prace górnika i hutnika w starożytnej Grecji, Warszawa: Państwowy Zakład Wydawniczy.

More T. (1954), Utopia, Warszawa: PAX.

Ortega y Gasset J. (1982), Bunt mas i inne pisma socjologiczne, Warszawa: PWN.

Ossowska M. (1963), Socjologia moralności, Warszawa: PWN.

Platon (1958), Państwo, Warszawa: PWN.

Poniatowski Z. (1965), Treść wierzeń religijnych, Warszawa: Książka i Wiedza.

Pszczołowski T. (1966), Praca człowieka, Warszawa: Wiedza Powszechna.

Ptaśnik J. (1959), Kultura wieków średnich, Warszawa: PWN.

Rabelais F. (1949), Gargantua i Pantagruel, Warszawa: PWN.

Rostovtzeff M. (1929), Gesellschaft und Wirtschaft im Römischen Kaiserreich, Bd. 1, Leipzig.

Scheler M. (1960), Die Wissensformen und Gesellschaft, [w:] Gesammelte Werke, Bd. 8, Bern.

Seneka L.A. (1961), Listy moralne do Lucyliusza, Warszawa: PWN.

Staszic S. (1954), Pisma filozoficzno-spoteczne, Warszawa: PWN.

Staszic S. (1959), Ród ludzki, Warszawa: PWN.

Sztajerman H. (1960), Społeczeństwo zachodniorzymskie w III wieku, Warszawa: PWN.

Sztumski J. (1997), Od cywilizacji pracy do cywilizacji bezrobocia, „Edukacja Dorosłych. Kwartalnik", nr 3.

Tawney R.H. (1963), Religia a powstanie kapitalizmu, Warszawa: Książka i Wiedza.

Thils G. i in. (1962), Travail et conditio humaine. Semaine des intellectuels catoliques.

Thurnwald R. (1932), Die menschliche Gesellschaft in ihren ethno-soziologischen Grundlagen, Bd. 3, Berlin-Leipzig.

Tilgher A. (1962), Work through the Ages, [w:] S. Nosow, W.H. Form (eds.), Man, Work and Society, New York.

Troeltsch E. (1906), Die Bedeutung des Protestantismus für die Entstechung der modernen Welt.

Ven F. van der (1972), Sozialgeschichte der Arbeit, Bd. 1, München.

Voltaire (1951), Kandyd, czyli optymizm, Warszawa: PWN. 
Weber M. (1905), Die protestantische Ethik und der Geist des Kapitalismus, Archiv für Sozialwissenschaft und Sozialpotik, Bd. 20-21.

Wyszyński S. (1957), Duch pracy ludzkiej, Poznań: Księgarnia św. Wojciecha.

\section{SUMMARY}

Work is a very important activity for Homo sapiens, because it has distinguished this species from the animal world and enabled it to create other civilizations, which testifies to its psychophysical development. Although work has always been the key factor stimulating the phylogenetic development of people, and is likely to continue to do so, this fact was recognized only after people had become capable of scientific reflection on work. This article constitutes an attempt at presenting the process of shaping views on the moral value of human work and the factors conditioning the prevailing views on this issue.

Keywords: human work; work as a value; the review of concepts; moral value of work 